\title{
E-learning and m-learning as tools for enhancing teaching and learning in higher education: a case study of Russia
}

\author{
Oksana Marunevich ${ }^{1, *}$, Valentina Kolmakova ${ }^{2}$, Irina Odaruyk ${ }^{1}$, and Denis Shalkov ${ }^{2}$ \\ ${ }^{1}$ Rostov State Transport University, Rostov-on-Don, Russia \\ ${ }^{2}$ Don State Technical University, Rostov-on-Don, Russia
}

\begin{abstract}
In the world of online education, teachers are constantly looking for ways to interact with students both synchronously and asynchronously. The next decade is likely to witness a considerable rise in the development of more advanced e-learning and m-learning tools since they have become a vital factor for education due to the global shutdown of learning activities forced by the COVID-19 pandemic. This paper is a preliminary attempt to analyze the use of e-learning and m-learning technologies by Russian universities. E-learning and m-learning mean sharing knowledge and skills by using web- or mobile-based technology, respectively. The most commonly employed learning tools are social networks, LMS, and video conferencing which due to their accessibility, immediacy, interactivity, and context-awareness benefit both teachers and students in a number of ways.
\end{abstract}

\section{Introduction}

The unexpected outbreak of the COVID-19 pandemic caused by the rapid spread of SARSCoV-2 affected all countries across the globe and negatively impacted the lives and wellbeing of millions of people. One of the most crucial closures during the world's health crisis is school systems and universities. As stated by the World Bank Group, by 24 April 2020, education establishments in about 180 countries were closed, causing approximately 1.5 billion students ( $85 \%$ of the total student population) to stay out of the in-person classroom [1]. As for higher education, nearly 220 college and university students ( $99 \%$ worldwide) have their studies or research activities ended [2]. It has resulted in the colossal migration of universities to online learning services and platforms, as well as mobile solutions.

Prior to the evolution of the internet, students could enjoy distance courses. The first attempts to introduce distance education technologies were made in the United States as early as 1728. Caleb Phillips, a teacher from Boston, Massachusetts, advertised the first shorthand correspondence classes by mail [3]. However, distance learning is not a part of American history only. Sweden and Great Britain offered correspondence courses in 1833 and 1840, respectively. In the 1840s, Isaac Pitman, a developer of the most commonly used system of shorthand, predominantly taught his students shorthand by correspondence. In

\footnotetext{
* Corresponding author: oks.marunevich@mail.ru
} 
1858, the University of London launched external training programs for students who for some reason could not afford full-time university study. Gustav Langenscheidt and Charles Toussaint were the first to offer language lessons in Germany in 1856. Correspondence tuition for Australian school children goes back to 1909. In response to political pressure from Queensland voters who demanded more convenient and less costly access to university education, in 1911, the University of Queensland was the first university in the southern hemisphere and one of the first around the world, in general, to offer correspondence courses with the possibility of getting a Bachelor's degree. Distance learning was also introduced into the educational curriculum of the Royal Institute of Technology and the University of Western Australia in 1919 and 1921, respectively [4]. In 1954, Burrhus Frederic Skinner, a professor of psychology at Harvard University, designed a teaching machine aimed at administering a curriculum of programmed learning. In the early 1960s, a research team of the University of Illinois led by Donald Bitzer presented the first distributed computer-based learning system recognized as PLATO (Programmed Logic for Automated Teaching Operations). Since the 1970s, e-learning has become a powerful tool in disseminating information to students' audiences.

As for Russia, the official status of e-learning was provided by the Concept for the Creation and Development of a Unified System of Distance Education in Russia, adopted by the State Committee of the Russian Federation for Higher Education on May 31, 1995. Even though the Concept underlined the positive social impact of e-learning and focused on its need due to its ability to create a unique and individual experience for each learner, the draft has never come into force. In 2002, the Ministry of Education issued Order No. 4452 "Methodology for the Application of E-Learning Technologies in Educational Institutions of Higher, Secondary and Additional Professional Education in the Russian Federation". Currently, e-learning is regulated by the provisions of the Federal Law "On Education", adopted on December 29, 2012, in which e-learning is defined as educational technologies implemented with the use of information and telecommunication networks with the indirect interaction between students and educators. According to the aforementioned legal act, elearning aims to provide high-quality and affordable education.

Thus, in the 21 st century, e-learning and m-learning is no longer a novel phenomenon for both educators and learners, but "a mainstream, pervasive learning delivery medium relied upon by thousands of educational institutions and millions of workforce" [5].

\section{Literature Review}

Breakneck developments in technology have made contemporary education easier than ever before. In the literature, e-learning usually refers to computer-enhanced or technologyenhanced learning. According to Kahiigi et al. [6], it is the acquisition of knowledge and skills by employing electronic technologies such as computers and the Internet. It gives an opportune occasion to get access and share learning materials in diverse formats including MS Word, PDF, PPT slideshows, audio, and videos for demonstrating, chatting, and messaging with a teacher or other students. Means et al. [7] put forward a new definition of e-learning, stressing the compulsory educational usage of technological devices, tools, and the Internet. Tallent-Runnels and co-authors [8] point out that the non-stop growth of technological innovation, internet accessibility, and digital transformation in the educational environment has significantly increased the motivation for e-learning globally since 2000. On the other hand, Joshi et al. [9] came to the conclusion that the advantages of e-learning are rather questionable due to the absence of face-to-face interaction between a teacher and students.

Besides, e-learning is interpreted as the use of any of the new technologies or applications in the service of learning or learning support [10], as educational content or 
learning experience delivered or enabled by electronic technologies [11]. Singh \& Thurman [12] use this term to nominate "learning experiences in synchronous or asynchronous environments using different devices (e.g. mobile phones, laptops, etc.) with internet access. In these environments, students can be anywhere (independent) to learn and interact with instructors and other students". As stated by Sharma \& Kitchens [13], e-learning is the delivery of learning through advanced technology and web-based training facilities (virtual universities and classrooms) that make teacher - student or student - student digital collaboration possible. Thus, most of the definitions have in common the ability to exploit a computer connected to a network, which gives the opportunity to learn anytime from anywhere with any means. Broadly, we can define e-learning as an active application of multi-purpose electronic devices (personal computer, laptop, e-readers, smartphones, etc.), Internet, intranets/extranets, interactive TV or satellite broadcast for both educational content delivery and cooperation between the participants of the learning interaction.

Kolmakova et al. $[14,15]$ state that e-learning can be integrated into the multimedia edutainment applications aimed at facilitating in-class communication in various ways, including games, short messages, quizzes, and multimedia content. Besides, it was found that the e-course content is typically divided into six categories such as pushing, messaging, response and feedback, file exchange, posting, and classroom communication [16].

Elliott Masie, a prominent educational expert credited with coining the term "elearning" to identify and characterize online learning, draws attention that alongside technology e-learning incorporates self-motivation, which he calls the "engine" of learning [17]. Indeed, motivation affects what we learn, how we learn, and when we choose to learn. Previous research [18, 19] demonstrates that motivated students tend to undertake challenging activities, are actively engaged, and manifest enhanced performance, creativity, and persistence.

In recent years there has been considerable interest in mobile learning as well. Mobile learning, usually named m-learning, is learning based on the wide use of small, portable computing devices, for instance, smartphones, personal digital assistants (PDAs), and similar handheld devices. Clark [20] interprets m-learning as person-to-person mobile communication within the learning environment. According to Polsani [21], m-learning is a form of learning method produced, circulated, and consumed in the network. Feser [22] explicates m-learning as mobile technology used to assist in learning, referencing, or exploring the information useful to a learner at that moment.

It is worth mentioning that m-learning is the subset of e-learning. For example, Quinn [23] defines m-learning as e-learning through mobile computational devices (Palms, Windows CE machines, and cell phones). Podlacha et al. [24] also comment on the close relationship between e-learning and m-learning. Hoppe et al. [25] state that e-learning implies the support of digital electronic tools and media, while m-learning exploits mobile devices and wireless transmission. However, Sanchez-Prieto et al. [26] argued that mlearning is directly related to e-learning. The authors regard it as an independent method of learning through its learning process has an electronic context.

In other words, e-learning and m-learning enable students to learn anywhere and anytime irrespective of their geographical locations. Among the obvious advantages of both types of learning are flexible timing and location, improved student-to-student and teacherto-student communication, available and accessible course materials, increased learners' confidence, composure, and motivation. 


\section{Methodology}

The given paper is a descriptive case study that provides insight into how e-learning and $\mathrm{m}$ learning intensify learning and teaching in educational institutes of Russia. We analyzed 73 universities (Rostov State Transport University, Don State Technical University, Pyatigorsk State University, Chuvash State University, St. Petersburg State University of Industrial Technology and Design, Ulyanovsk State Technical University, etc.) located in Southern, North Caucasian, Northwestern, Volga, Central, and Siberian Federal Districts. We use the descriptive research method to focus on describing the peculiar features and models of elearning and m-learning practices at large Russian universities during the COVID-19 pandemic.

\section{Results \& Discussion}

This section scrutinizes the active application of e-learning and m-learning tools in form of video conferencing, digital libraries, virtual tutoring, online courses, learning software, etc. due to a massive demand for education connectivity during a new pandemic era.

First of all, it is necessary to indicate that there are two types of e-learning and $\mathrm{m}$ learning based on the method of obtaining information. They are synchronous and asynchronous online learning. Synchronous e-learning is a teacher-led method that provides real-time communication via videoconferencing and/or chatting. It implies the online presence of both students and teachers during the lesson session since it allows them to share knowledge or ideas, asking and answering questions with instant response. Analyzing the benefits of synchronous e-learning, Hrastinski lists the potential of this method to make education more social and evade frustration [27].

Asynchronous e-learning is a self-regulated learning method in a form of e-mail and discussion boards that support the learning process even if the teacher and students are offline. It is a fundamental component of flexible e-learning. Course materials are delivered via the web or email and can be uploaded when required. In turn, students log in to the educational environment at any time to download materials, send messages to teachers, check or refine their tasks, which are commonly considered more thoughtful in contrast to the synchronous method. Actually, a lot of people prefer online courses because of their asynchronous qualities and the possibility to combine education with work, doing sports, social activities, etc.

Unlike American and European universities (e.g. Vanderbilt University, University of Arkansas, Indiana University, Gdańsk University of Technology, University of Leuven), the Russian ones do not tend to send course materials to students by email. Similarly, the institution management mails policies or any other university-related regulations neither students nor the staff.

Social networks, e.g. Facebook, VK, WhatsApp, YouTube, Wikipedia, etc. provide convenient means of communication and learning between students and educators, as well as between the students. As a rule, students create groups to discuss diverse academic and administrative issues of the class. However, prior to the lockdown, teachers used them rather informally, though previous researches on their usage in higher education [28-31] have demonstrated that they can are perfect for supplementing traditional learning and enhancing students' learning experience. But the COVID-19 pandemic has pushed universities to look for alternatives to the traditionally-based learning system. Our study shows that currently a lot of Russian universities have a robust use of social networks $(70.2 \%, \mathrm{n}=54)$. For instance, Design Department of Moscow University for the Humanities, Foreign Languages Chair of the Peoples' Friendship University of Russia, 
Mathematics, Physics and Medical Informatics Chair of Ryazan State Medical University, Economics, Management and Law Department of Rostov State Transport University have official pages in VK social network, while Department of Financial Law of the Southern Federal University, Department of Theoretical and Applied Linguistics of Moscow State University, Department of Artistic Metal Processing of Saint Petersburg Stieglitz State Academy of Art and Design, Pedagogy and Vocational Training Methodology Chair of Volgograd State Agrarian University encourage their faculty members to communicate with students using formal groups on Facebook. Although a recent study found that Facebook and WhatsApp are the most employed tools in higher education for direct academic interaction [29], Russian social network VK is still popular among both teachers and students because of its intuitive interface and user-friendly design.

Approximately $90 \%$ (68 universities out of 73) of our sample satisfied students' demands for knowledge during the pandemic without the need to meet in a class by using Learning Management System (hereafter LMS). LMS is defined as an educational space, with connects students and teachers. The latter upload course materials, tests, and tasks. In return, students submit their home assignments or ask questions to the teacher. To work in LMS, both the students and teachers have to log into the system. Login is typically the number of a student's ID card. After the first logging, the system asks users to change the automatic password. In their personal LMS account, students only see the courses they are taking at the moment. There are many LMS in the higher education space of Russia, yet the top solution is Moodle. With customizable management features, it is used to create private websites with online courses to achieve learning goals.

The key feature of any LMS is that it enables mobile access thus fostering m-learning. A recent study from Pearson [32] found that nine in ten $(92 \%)$ college and university students regularly use a smartphone. When asked about the future in-class use of mobile devices, three in five $(60 \%)$ students would like to use mobile technologies more often than they do now.

The implementation of social awareness issued by the educational institutions during the COVID-19 pandemic has affected the use of synchronous learning tools, like video conferencing. Video conferencing has a wide array of benefits for both students and teachers. First of all, it is the interaction in real-time, similar to those that occur in a traditional classroom. Previous research found that students who participated in video conferencing felt more motivated and less stressed when preparing for exams [33]. Research also demonstrates that videoconferencing results in higher levels of student engagement [34]. Besides, video conferencing allows educators to reach multiple students at once and more immediately than email or messaging in the asynchronous e-learning environment. Russian universities apply free online meeting platforms, especially Zoom $(71.5 \%$ of the cohort, $\mathrm{n}=55)$, Google Classroom $(9.1 \%, \mathrm{n}=7)$, and Microsoft Teams (14.3 $\%, \mathrm{n}=11)$.

Authors' experience and interviews with colleagues indicated that early efforts to incorporate synchronous video conferencing into the learning environment were invalid. Both students and teachers were unfamiliar with these platforms since they did not receive any training and the shift to online learning was rather unexpected. However, later, the use of video conferencing increased student's attendance rate, motivation, and engagement. With this new experience of online learning, the interviewed subjects agreed that video conferencing assisted them in achieving their course's intended learning outcomes.

Taken together the aforementioned e-learning and m-learning tools provide students with a comprehensive learning experience. At the same time, teachers should give more attention to interactivity, creativity, student support, and building a strong online community. Special support and encouragement should be given to first-year students who are new at university, as well as e-learning and m-learning experience. 


\section{Conclusion}

This paper has stressed the experience of Russian universities in implementing e-learning and m-learning practices in their educational processes during the COVID-19 pandemic. Our findings support the idea that e-learning and m-learning tools are web-based platforms that provide higher education with diverse means of improving teaching and learning activities. Alongside enhancing students - teacher relationships, they increase students' motivation and engagement.

Our work has led us to the conclusion that the importance of e-learning and m-learning in the current conditions of the COVID-19 health crisis in the world is difficult to overestimate. Russian universities adopt diverse e-learning and m-learning interactions (social networks, LMS, video conferencing) for the continuation of teaching and learning.

\section{References}

1 The COVID-19 pandemic: Shocks to education and policy responses: World Bank Group Report (2020)

2 The COVID-19 crisis response: Supporting tertiary education for continuity, adaptation, and innovation. Retrieved from http://documents1.worldbank.org/curated/en/621991586463915490/The-COVID-19Crisis-Response-Supporting-Tertiary-Education-for-Continuity-Adaptation-andInnovation.pdf

3 B. Holmberg, The Evolution, Principles and Practices of Distance Education, Oldenburg: Studien und Berichte der Arbeitsstelle Fernstudienforschung der Carl von Ossietzky Universität (2013).

4 O.V. Marunevich, Distance learning technologies in Australia: history, problems, and prospects In Modern digital, information and communication technologies for forming universal competencies of university students in the process of teaching foreign languages / T. Isaeva (ed). Rostov-on-Don, pp. 139-158 (2020).

5 E.J. Cherian, P. Williams, Mobile learning: the end of classroom learning, In Proceedings of the World Congress on Engineering and Computer Science, IAENG publisher, San Francisco (2008).

6 E.K. Kahiigi, L. Ekenberg, H. Hansson, F.F. Tusubira, \& M. Danielson, Exploring the e-Learning State of Art (2008), Retrieved from www.ejel.org/issue/download.html?idArticle $=67$

7 B. Means, Y. Toyama, R. Murphy, M. Bakia, \& K. Jones, Evaluation of evidence-based practices in online learning: A meta-analysis and review of online learning studies (2009).

8 M. K. Tallent-Runnels, J. A.Thomas, W. Y. Lan, S. Cooper, T.C. Ahern, S.M. Shaw, \& $\mathrm{X}$. Liu, Teaching courses online: A review of the research, Review of Educational Research, 76 (1), 93-135 (2006) https://doi.org/10.3102/00346543076001093

9 O. Joshi, B. Chapagain, G. Kharel, N.C. Poudyal, B.D. Murray, \& S.R. Mehmood, Benefits and challenges of online instruction in agriculture and natural resource education, In Interactive Learning Environments, pp. 1-12 (2020). http://doi.org/10.1080/10494820.2020.1725896

10 D. Laurillaard, Rethinking University Teaching: A Conversational Framework for the Effective Use of Learning Technologies, London: Routledge Falmer (2002).

11 C.S. Ong, J.Y. Lai, \& Y. S. Wang, Factors Affecting Engineers' Acceptance of Asynchronous E-learning Systems in High-Tech Companies. Information and Management, 41 (6), pp. 795-804 (2004). 
12 V. Singh \& A. Thurman, How Many Ways Can We Define Online Learning? A Systematic Literature Review of Definitions of Online Learning (1988-2018), American Journal of Distance Education, 33(4), pp. 289-306 (2019). DOI: $10.1080 / 08923647.2019 .1663082$

13 S.K. Sharma, \& F.L. Kitchens, Web services architecture for M-learning, Electronic Journal on e-Learning, 2(1), pp. 203-216. (2004).

14 V.V. Kolmakova, D.Yu. Shalkov, E.S. Shilova, Edutainment as the technology to form cognitive descriptors in learning English, Proceeding of international scientific and practical conference The teacher of a higher school in the 21st century, 16, pp. 183-193 (2019).

15 D.Yu. Shalkov, V.V. Kolmakova, Quest technology as an effective way to form student's associative thinking, Proceeding of the international scientific and practical conference The teacher of a higher school in the 21st century, 13 (1), pp.155-162 (2016).

16 O.V. Marunevich, I.V. Odaryuk, Concept as a knowledge formation unit in the process of teaching foreign language at technical university, Proceedings of the conference Legal science in the XXI century: current problems and prospects for their solutions. pp. 171-173 (2020).

17 E. Masie, Learning Rants, Raves, and Reflections: A Collection of Passionate and Professional Perspectives, 1st edition, Pfeiffer (2005).

18 M.K. Hartnett. The Importance of Motivation in Online Learning, In Motivation in Online Education. Massey University (2016). DOI: 10.1007/978-981-10-0700-2 2

19 M.E. Shevchuck, O.V. Marunevich, Concept Railway as a unit of knowledge formation in the process of studying a foreign language at transport university, Proceedings of the All-Russian scientific-practical conference with international participation Rational Environmental Management as the Basis of Sustainable Development, Chechen State Pedagogical University, pp. 540-544 (2020).

20 J.D. Clark, Learning and Teaching in the Mobile Learning Environment of the TwentyFirst Century. Austin: Austin Community College (2007).

21 P. Polsani, Network learning, In Mobile Learning Essay on Philosophy, Psychology, and Education, Vienna: Passage Verlag, pp. 139-150 (2003).

22 J. Feser, m-Learning is not e-Learning on a mobile device, John Wiley \& Sons (2010).

23 C. Quinn, M-Learning mobile, wireless, in your pocket learning (2000). Retrieved from http://www.linezine.com/2.1/features/cqmmwiyp.htm

24 G. Podlacha, C. Alscher, \& S. Amaya, Digital adult education - A key to global development? (2016), Retrieved from international.de/fileadmin/files/Inhalte_Bilder_und_Dokumente/Materialien/IPE/IPE_7 3 web.pdf

25 H.U. Hoppe, R. Joiner, M. Milrad, Guest editorial: Wireless and mobile technologies in education, Journal of Computer Assisted Learning, 19(3), pp. 255-259 (2003).

26 J.C. Sanchez-Prieto, S. Olmos-Miguelanez, \& F.J. Garcia-Penalvo, Informal tools in formal contexts: Development of a model to assess the acceptance of mobile technologies among teachers, Computers in Human Behavior, 55(Part A), pp. 519-528 (2016).

27 S. Hrastinski. Asynchronous \& Synchronous E-learning, Education Quarterly, 31(4), pp 51-55 (2008).

28 A. Sobaih, M. Moustafa, Speaking the same language: The value of social networking sites for hospitality and tourism higher education in Egypt, J. Hosp. Tour. Educ, 28, pp. 21-31 (2016). 
29 S. Manca, Snapping, pinning, liking or texting: Investigating social media in higher education beyond Facebook, Internet High. Educ, 44 (2020). https://doi.org/10.1016/j.iheduc.2019.100707

30 I. Awidi, M. Paynter, \& T. Vujosevic, The Facebook group in the learning design of a higher education course: An analysis of factors influencing positive learning experience for students, Comput. Educ, 1, pp. 106-121 (2019).

31 A. Al-Aufi, C. Fulton, Use of social networking tools for informal scholarly communication in humanities and social sciences disciplines, Procedia Soc. Behav. Sci., 147, pp. 436-445 (2014).

32 Pearson's National Report: Student Mobile Device Survey (2020), Retrieved from https://www.pearson.com/

33 D. P. II Rudd, \& D. P. Rudd, The value of video in online instruction, Journal of Instructional Pedagogies, 13, pp. 1-7 (2014).

34 E. Acosta-Tello, Enhancing the online class: Effective use of synchronous interactive online instruction, Journal of Instructional Pedagogies, 17, pp. 1-6 (2015). 